\title{
Aanwijzingen voor auteurs
}

a) De auteurs worden verzocht een kopij in drievoud te zenden, getypt met dubbele interlinie en brede marge, of een floppy disk (1).

b) Elk artikel moet voorafgegaan worden door een korte samenvatting in het Engels en minimum drie Engelse trefwoorden.

c) Ook een korte identifikatie van de auteur moet bezorgd worden : naam, adres en specialisatie van het onderzoek.

d) De auteurs dienen in hun kopij duidelijk aanwijzingen te geven betreffende indelingen van hoofdstukken, paragrafen,... Citaten moeten eveneens duidelijk worden aangegeven.

e) Indien de auteur gebruik maakt van illustraties moet hij voor de reproduktie geschikt materiaal leveren. Alle illustraties zijn in zwart/wit. Lijnillustraties moeten na eventuele verkleining leesbaar blijven tot op DIN A7. Alle formaten worden verkleind tot minimum DIN A7 (10 x 7) en maximum DIN A5 (21 $\mathrm{x}$ 15).

f) Noten moeten doorlopend genummerd worden in de tekst en achteraan bij de tekst toegevoegd worden.

g) Bibliografische aanduidingen, verwijzingen en citaten kunnen aangebracht worden zoals binnen de verschillende disciplines gebruikelijk is.

h) Iedere auteur ontvangt 3 nummers.

(1) BELANGRIJK : Bij voorkeur worden de teksten op floppy disk gezet. Om rechtstreekse overname mogelijk te maken worden de auteurs verzocht vooraf kontakt op te nemen met het sekretariaat.

\section{Instructions for authors}

a) Authors are requested to send three copies of their typewritten manuscript (double-spaced and with ample margins), or a floppy disk with the article in WordStar or Word Perfect (1).

b) The author is requested to provide a short summary in English and at least three English keywords.

c) A short identification of the author is also to be provided : name, address and a short description of current research.

d) Authors should clearly indicate the divisions in chapters and paragraphs. Quotations should be clearly indicated.

e) If illustrations are used, the author must provide them in suitable form for reproduction. All illustrations will be printed in black and white. Graphs should be legible after reduction to DIN A7. All sizes will be reduced to a minimum of DIN A7 $(10 \times 7 \mathrm{~cm})$ or to a maximum of DIN A5 $(21 \times 15 \mathrm{~cm})$.

f) Notes are indicated in the text by numbers in sequence and are listed separately.

g) Bibliographical indications, references and quotations can be marked as it is customary within the proper scientific discipline.

h) Authors will receive three copies.

(1) IMPORTANT : Providing the manuscript on a floppy disk (WordStar or WordPerfect) will be strongly appreciated by the editors. Please contact previously the secretariat for exact instructions about compatibility.

\section{Recommandations aux auteurs}

a) L'auteur est prié d'envoyer son manuscrit en 3 exemplaires, dactylographiés de préférence (avec interligne double et grandes marges). Nous encourageons l'envoi de disquettes (1).

b) Chaque texte doit être précédé d'un court résumé en anglais et d'au moins 3 mots-clés anglais.

c) Une brève note identifiant l'auteur est souhaitée: nom, adresse et domaine spécialisé d'études.

d) Les chapitres, paragraphes, alinéas etc. doivent être clairement indiqués, les citations explicitement signalées.

e) Les illustrations éventuelles doivent se prêter à la reproduction. Toutes les illustrations sont en noir et blanc. Les graphiques doivent rester lisibles après réduction à DIN A7. Tous les formats seront réduits à DIN A5 (réduction min. de $21 \times 15 \mathrm{~cm}$ ) et à DIN A7 (réduction max. de $10 \times 7 \mathrm{~cm}$ ).

f) Les notes et additions (numérotage continu) sont assemblées séparément à la fin du texte.

g) Les indications bibliographiques, les références et les citations seront indiquées conformément à l'usage dans les différentes disciplines scientifiques.

h) Chaque auteur recevra trois exemplaires d"Afrika Focus".

(1) IMPORTANT. Les éditeurs encouragent la réception des articles manuscrits sur disquette souple ('WordStar' ou 'WordPerfect'). Les auteurs peuvent s'adresser au secrétariat pour toute information concernant la compatibilité des disquettes. 